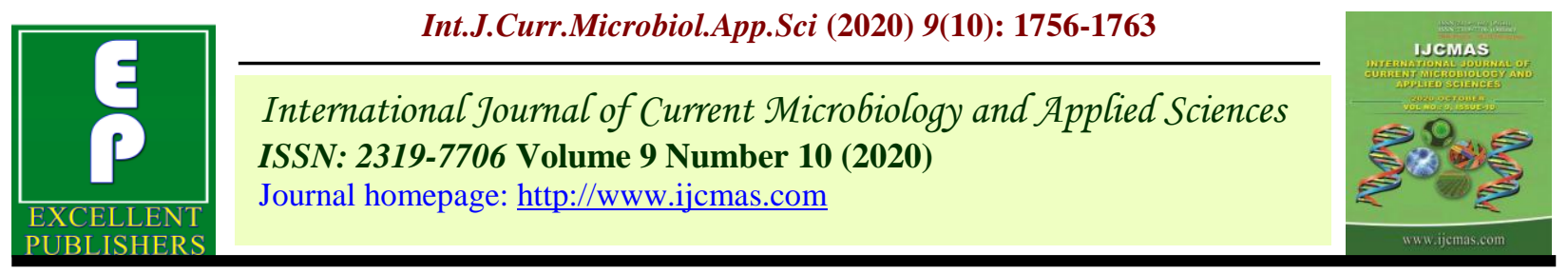

\title{
Determination of Mutagenic Sensitivity in Hibiscus rosa-sinensis L. (Cultivar Red Single) to Physical and Chemical Mutagens
}

\author{
N. Naveena ${ }^{1 *}$, S. Subramanian ${ }^{2}$, M. Jawaharlal ${ }^{3}$, K. Iyanar $^{4}$ and C. N. Chandrasekhar ${ }^{5}$ \\ ${ }^{1}$ Department of Floriculture \& Landscape Architecture, ${ }^{2}$ Horticultural College \& Research \\ Institute, ${ }^{3}$ Directorate of Extension Education, ${ }^{4}$ Department of Millets, Tamil Nadu \\ Agricultural University, Coimbatore, India \\ ${ }^{5}$ Agricultural College, Research Institute, Tamil Nadu Agricultural University, \\ Coimbatore, India \\ *Corresponding author
}

\section{A B S T R A C T}

\begin{tabular}{|l|}
\hline Key w or d s \\
Hibiscus cv. Red \\
Single, Mutation, \\
Gamma radiation, \\
Sensitivity, \\
Survival, $\mathrm{LD}_{50}$
\end{tabular}

\begin{abstract}
Hibiscus, being an potential ornamental shrub needs improvement in terms of architecture. Mutation breeding technique has been considered as an efficient tool for vegetatively propagated crops. For every mutation breeding experiment, determination of mutagenic sensitivity is an important step because it varies with every species and varieties. Based on this, investigation on the induction of mutation in Hibiscus rosa-sinensis L. was carried out with the objective of creating genetic variability through physical mutagen viz., gamma rays and Ethyl Methane Sulphonate (EMS). In this study, hard wood cuttings of Hibiscus rosa-sinenis Cultivar Red Single were treated with nine different dose of gamma rays (1 to $5 \mathrm{k} \mathrm{R}$ ) and ten different concentrations of EMS ranging from $0.1 \%$ to $1.0 \%$. The results revealed that gradual reduction in survival of cuttings, shoot length, leaf length and leaf width with increase in dosage of gamma rays and EMS. However gamma rays treated plants showed significant gradual reduction in growth rate than the EMS treated plants. Based on probit analysis, $\mathrm{LD}_{50}$ (Lethal dose) value for gamma radiation and EMS have been fixed as $2.81 \mathrm{kR}$ and $0.89 \%$ respectively.
\end{abstract}

\section{Introduction}

In recent years floriculture industry is improving by introducing many novel cultivars in the market. Exploration of flower crops and their utilities raising everywhere. Many ornamental flower crops contributes beauty in landscaping particularly perennial shrubs plays a prominent role in establishing gardens. Hibiscus regarded as a standard flowering shrub known for its traditional, medicinal and commercial value. Hibiscus rosa-sinensis $\mathrm{L}$. is a traditional flower native of Asia and the Pacific Islands, which is grown all over the world. Hibiscus cultivar Red Single was found to be completely sterile and hardy in nature. Crop improvement in asexually propagated flower crops like Hibiscus, Jasmine, Bougainvillea, Tuberose, gladiolus can be carried out by various breeding methods. Only a limited number of combined desirable characters with a reasonable degree of fertility could be used as parents for the Hybridization breeding 
programme. Whereas Mutation breeding is a suitable option to enhance genetic variability and to improve economic traits in ornamentals. Induced mutation which leads to altered phenotypes after permanent heritable change in the structure of the genetic material (Rego and Faria, 2001) is now established as a time-saving and inexpensive approach for flower improvement (Datta and Da Silva, 2006).

Selecting appropriate mutagen, treatment method and correct dose are essential in performing a mutation breeding programme. Different type of mutagens can be employed to induce mutagenesis in vegetatively propagated crops. Physical mutagens have been extensively used for the development of new cultivars with improved characteristics in vegetatively propagated ornamental plants (Kumar et al., 2006). The frequency and saturation of mutations can be regulated by varying the mutagen dose (Menda et al., 2004) and mutagenic agents can induce different extensions of genomic lesions, ranging from base mutations to larger fragment insertions or deletions (Kim et al., 2006). Gamma irradiation is considered to be more suitable for obtaining mutants with less radiation damage (Yamaguchi et al., 2010).

In case of chemical mutagens, alkylating agents such as Methyl Methane Sulphonate (MMS), Ethyl Methane Sulphonate (EMS) and Nitroso Guanidine (NG) have been reported to have several effects on DNA (Anon, 1977). Among the alkylating chemical mutagens, Ethyl Methane Sulphonate (EMS) is a popular mutagenic and carcinogenic organic compound that generates random mutations in genetic content through nucleotide substitution. It is a popular mutagenic agent, only produces point mutations (Okagaki et al., 1991). To avoid excessive loss of actual experimental materials, sensitivity tests must be conducted to determine $\mathrm{LD}_{50}$ doses (the safe dose at which half of the planting materials survive) before massive irradiation/treatment of similar materials is accepted. Based on this, the present study was framed to determine the optimum lethal dose $\left(\mathrm{LD}_{50}\right)$ for gamma radiation and EMS in Hibiscus Cultivar Red Single.

\section{Materials and Methods}

Hibiscus rosa-sinensis L. Cultivar Red Single is a perennial bushy shrub commonly grown in south India, used as parent in this study which has dark green ovate leaves with serrate margins and has single whorl of dark red flowers. Gamma rays, a physical mutagen and Ethyl Methane Sulphonate (EMS), a chemical mutagen used to induce mutation to achieve variability. Hard wood cuttings of uniform size (25 cuttings per treatment) usually $15-18 \mathrm{~cm}$ length with pencil thickness collected and subjected to different doses/concentration of gamma radiation and EMS. Gamma irradiation was given in gamma chamber located at Indian Institute of Horticultural Research (IIHR), Bengaluru which has ${ }^{60} \mathrm{Co}$ as gamma source. This gamma radiation was given at nine different doses viz., $1 \mathrm{kR}, 1.5 \mathrm{kR}, 2 \mathrm{kR}, 2.5 \mathrm{kR}, 3 \mathrm{kR}$, $3.5 \mathrm{kR}, 4 \mathrm{kR}, 4.5 \mathrm{kR}$ and $5 \mathrm{kR}$. In case of chemical mutagenesis, Cuttings of desired specification were soaked in water for 1 hour. After that, cuttings were soaked in EMS solution which is freshly prepared in phosphate buffer ( $\mathrm{pH}$ 7.0) of different concentrations viz., $0.1 \%, 0.2 \%, 0.3 \%, 0.4 \%$, $0.5 \%, 0.6 \%, 0.7 \%, 0.8 \%, 0.9 \%, 1.0 \%$ for 6 hours. After 6 hours, cuttings are subjected to washing in tap water before planting.

Finally the treated cuttings of both gamma rays and EMS were planted in the polythene bags containing Red soil: FYM: Sand in the ratio of $1: 1: 1$ and maintained separately in mist chamber for rooting. The percentage 
survival, Shoot length, leaf length, leaf width were measured 45 days after planting incase of gamma radiation whereas in EMS treated plants, observations recorded 30 days after planting. This is because of delayed response in gamma ray treated plants. The experiment was organized as CRD with three replication. The $\mathrm{LD}_{50}$ value was calculated based on probit analysis.

\section{Probit analysis}

$\mathrm{LD}_{50}$ values of gamma radiation and EMS were determined based on Finney's method (Finney, 1978). Probit analysis was carried out in MS Excel by following procedure with some modification in log-doses (Mentioned in the procedure).

The dose concentration of mutagen is transformed into $\log _{10} 3$ value.

The mortality percentage of seeds due to treatment doses are worked out and rounded to the nearest whole number.

The corrected mortality percentage is calculated using Abbott's formula given below.

: orrected mortality $(\%)=\frac{M_{\text {observed }}-M_{\text {control }}}{100-M_{\text {control }}} \times 100$

All the corrected values are rounded to the nearest whole number.

The corrected values are converted to the probit transformation.

Probit values (Y-axis) are graphed against Log concentration (X-axis) and a straight line passing through most of the plotted points is drawn; then this line is used to estimate the $\log _{10}$ concentration associated with a probit of 5 .

Antilog to the $\log _{10} 3$ value corresponding to the probit 5 was taken and the arrived value was divided by $10^{-3}(1000)$, thus
$\mathrm{LD}_{50}$ for the particular mutagen under study is determined.

\section{Analysis of variance}

Data obtained for growth related traits were subjected to analysis of variance (ANOVA) at the significant level of $5 \%$ using SPSS software. When statistical differences were found, the least significant difference (LSD) was used to compare means at the 5\% significance level.

\section{Results and Discussion}

The results indicated that there was a gradual reduction in survival rate of cuttings with increase in dose of gamma rays and EMS (Table 1). Similar results of decline in the survival percentage has been reported by Anitha et al., (2017) in Bougainvillea spectabilis willd. (Cv. Lalbagh). This reduction in survival after exposure to gamma rays was due to inactivation or decrease in auxin content that affect cell division, it resulting in poor establishment and survival (Mahure et al., 2010). When comparing the two mutagens, mortality percentage was higher in gamma ray induced plants than EMS with increased treatments, at higher dose of EMS-1.0\%, Survival percentage was $32 \%$ whereas in higher treatment of gamma rays $(5 \mathrm{kR})$, only $8 \%$ of survival was found. This output confirms that chemical mutagens alone produced point mutations, whereas radiations normally caused chromosomal aberrations and deletions (Bhat et al., 2007). Similar kind of results in survival after exposure to gamma rays was reported by Kapadiya et al., (2014) in variety "Maghi".

$\mathrm{LD}_{50}$ value fixed by interpreting results of probit analysis (Fig.1 and 2). Probit analysis was carried out based on survival rate of stem cuttings after subjecting to different gamma ray treatments and EMS doses compared with 
untreated control (Table 1). In this study, $\mathrm{LD}_{50}$ value for gamma rays was found as 2.81 kR by probit analysis (Fig. 1). The gamma rays being more potent and highly penetrating in nature might have impacted the cells undergoing meiotic division in the bud region
(Deshpande et al., 2010). Considering this, growth rate also recorded to fix the $\mathrm{LD}_{50}$ in gamma radiation in narrow scale. Since $52 \%$ survival was observed in $3 \mathrm{kR}$ (Table 1), the range was fixed between 2 to $4 \mathrm{kR}$.

Table.1 Effect of gamma rays on survival of cuttings and probit analysis in Hibiscus rosa-sinensis L. cv. Red Single

\begin{tabular}{|l|l|l|l|l|l|l|l|l|l|}
\hline $\begin{array}{l}\text { Dose } \\
(\mathbf{k R})\end{array}$ & $\begin{array}{l}\text { Survival } \\
\text { (Nos.) } \\
\text { out } \\
\mathbf{2 5}\end{array}$ & $\begin{array}{l}\text { Survival } \\
\mathbf{( \% )}\end{array}$ & $\begin{array}{l}\mathbf{\%} \\
\text { over } \\
\text { control }\end{array}$ & $\begin{array}{l}\text { \% } \\
\text { reduction } \\
\text { over } \\
\text { control }\end{array}$ & $\begin{array}{l}\text { Observed } \\
\text { mortality } \\
\text { percentage }\end{array}$ & $\begin{array}{l}\text { Corrected } \\
\text { mortality } \\
\text { percentage }\end{array}$ & $\begin{array}{l}\text { Log } \\
\text { value } \\
\text { of } \\
\text { doses }\end{array}$ & $\begin{array}{l}\text { Empirical } \\
\text { probit } \\
\text { unit }\end{array}$ & $\begin{array}{l}\text { LD }_{\mathbf{5 0}} \\
\text { value }\end{array}$ \\
\hline $\mathbf{0}$ & 24 & 96 & 100.00 & -- & 4.00 & 0.00 & -- & -- & $\mathbf{2 . 8 1}$ \\
\hline $\mathbf{1 . 0}$ & 23 & 92 & 95.83 & 4.17 & 8.00 & 8.00 & 3.00 & 3.59 & kR \\
\hline $\mathbf{1 . 5}$ & 23 & 92 & 95.83 & 4.17 & 8.00 & 8.00 & 3.18 & 3.59 \\
\hline $\mathbf{2 . 0}$ & 20 & 80 & 83.33 & 16.67 & 20.00 & 20.00 & 3.30 & 4.16 \\
\hline $\mathbf{2 . 5}$ & 16 & 64 & 66.67 & 33.33 & 36.00 & 36.00 & 3.40 & 4.64 \\
\hline $\mathbf{3 . 0}$ & 13 & 52 & 54.17 & 45.83 & 48.00 & 45.83 & 3.48 & 4.90 \\
\hline $\mathbf{3 . 5}$ & 9 & 36 & 37.50 & 62.50 & 64.00 & 62.50 & 3.54 & 5.32 \\
\hline $\mathbf{4 . 0}$ & 6 & 24 & 25.00 & 75.00 & 76.00 & 75.00 & 3.60 & 5.67 \\
\hline $\mathbf{4 . 5}$ & 5 & 20 & 20.83 & 79.17 & 80.00 & 79.17 & 3.65 & 5.81 \\
\hline $\mathbf{5 . 0}$ & 2 & 8 & 8.33 & 91.67 & 92.00 & 91.67 & 3.70 & 6.38 \\
\hline
\end{tabular}

Table. 2 Effect of gamma rays on vegetative parameters of Hibiscus rosa-sinensis L. cv. Red Single

\begin{tabular}{|c|c|c|c|c|c|c|c|c|c|}
\hline \multirow{2}{*}{$\begin{array}{c}\text { Doses } \\
(\mathbf{k R})\end{array}$} & \multicolumn{3}{|c|}{ Shoot length $(\mathrm{cm})$} & \multicolumn{3}{|c|}{ Leaf length $(\mathrm{cm})$} & \multicolumn{3}{|c|}{ Leaf width $(\mathrm{cm})$} \\
\hline & Actual & $\begin{array}{l}\text { \%over } \\
\text { control }\end{array}$ & $\begin{array}{c}\% \\
\text { reduction } \\
\text { over } \\
\text { control }\end{array}$ & Actual & $\begin{array}{l}\text { \% over } \\
\text { control }\end{array}$ & $\begin{array}{c}\% \\
\text { reduction } \\
\text { over } \\
\text { control }\end{array}$ & Actual & $\begin{array}{l}\% \text { over } \\
\text { control }\end{array}$ & $\begin{array}{c}\% \\
\text { reduction } \\
\text { over } \\
\text { control }\end{array}$ \\
\hline $\mathbf{0}$ & 35.64 & 100 & --- & 4.87 & 100 & --- & 2.92 & 100 & --- \\
\hline 1.00 & 34.25 & 96.10 & 3.90 & 4.75 & 97.54 & 2.46 & 2.87 & 98.29 & 1.71 \\
\hline 1.50 & 28.95 & 81.23 & 18.77 & 4.65 & 95.48 & 4.52 & 2.75 & 94.18 & 5.82 \\
\hline 2.00 & 26.50 & 74.35 & 25.65 & 4.50 & 92.40 & 7.60 & 2.63 & 90.07 & 9.93 \\
\hline 2.50 & 26.13 & 73.32 & 26.68 & 4.28 & 87.89 & 12.11 & 2.35 & 80.48 & 19.52 \\
\hline 3.00 & 23.48 & 65.88 & 34.12 & 3.92 & 80.49 & 19.51 & 2.12 & 72.60 & 27.40 \\
\hline 3.50 & 21.33 & 59.85 & 40.15 & 3.65 & 74.95 & 25.05 & 1.58 & 54.11 & 45.89 \\
\hline 4.00 & 18.50 & 51.91 & 48.09 & 2.50 & 51.33 & 48.67 & 1.50 & 51.37 & 48.63 \\
\hline 4.50 & 15.75 & 44.19 & 55.81 & 2.15 & 44.15 & 55.85 & 1.35 & 46.23 & 53.77 \\
\hline 5.00 & 11.29 & 31.68 & 68.32 & 1.52 & 31.21 & 68.79 & 0.90 & 30.82 & 69.18 \\
\hline Mean & 24.18 & & & 3.68 & & & 2.10 & & \\
\hline $\mathrm{SE}(\mathrm{d})$ & 2.78 & & & 0.42 & & & 0.24 & & \\
\hline $\operatorname{CD}(5 \%)$ & 5.85 & & & 0.89 & & & 0.51 & & \\
\hline
\end{tabular}


Table.3 Effect of EMS on survival of cuttings and probit analysis in Hibiscus rosa-sinensis L. cv. Red Single

\begin{tabular}{|c|l|l|l|l|l|l|l|l|l|}
\hline $\begin{array}{l}\text { Dose } \\
(\boldsymbol{\%})\end{array}$ & $\begin{array}{l}\text { Survival } \\
\text { (Nos.) } \\
\text { out of } \\
\text { 25 }\end{array}$ & $\begin{array}{l}\text { Survival } \\
(\mathbf{\%})\end{array}$ & $\begin{array}{l}\text { \% } \\
\text { over } \\
\text { control }\end{array}$ & $\begin{array}{l}\text { \% } \\
\text { reduction } \\
\text { over } \\
\text { control }\end{array}$ & $\begin{array}{l}\text { Observed } \\
\text { mortality } \\
\text { percentage }\end{array}$ & $\begin{array}{l}\text { Corrected } \\
\text { mortality } \\
\text { percentage }\end{array}$ & $\begin{array}{l}\text { Log } \\
\text { value } \\
\text { of } \\
\text { doses }\end{array}$ & $\begin{array}{l}\text { Empirical } \\
\text { probit } \\
\text { unit }\end{array}$ & $\begin{array}{l}\text { LD 50 } \\
\text { value }\end{array}$ \\
\hline $\mathbf{0}$ & 24 & 96.00 & 100 & -- & 4.00 & -- & -- & -- & 0.89\% \\
\hline $\mathbf{0 . 1}$ & 23 & 92.00 & 95.83 & 4.17 & 8.00 & 4.20 & 2.00 & 3.27 \\
\hline $\mathbf{0 . 2}$ & 23 & 92.00 & 95.83 & 4.17 & 8.00 & 4.20 & 2.30 & 3.27 \\
\hline $\mathbf{0 . 3}$ & 21 & 84.00 & 87.50 & 12.50 & 16.00 & 12.50 & 2.48 & 3.85 \\
\hline $\mathbf{0 . 4}$ & 20 & 80.00 & 83.33 & 16.67 & 20.00 & 16.70 & 2.60 & 4.03 \\
\hline $\mathbf{0 . 5}$ & 18 & 72.00 & 75.00 & 25.00 & 28.00 & 25.00 & 2.70 & 4.33 \\
\hline $\mathbf{0 . 6}$ & 16 & 64.00 & 66.67 & 33.33 & 36.00 & 33.33 & 2.78 & 4.57 \\
\hline $\mathbf{0 . 7}$ & 15 & 60.00 & 62.50 & 37.50 & 40.00 & 37.50 & 2.85 & 4.68 \\
\hline $\mathbf{0 . 8}$ & 14 & 56.00 & 58.33 & 41.67 & 44.00 & 41.70 & 2.90 & 4.79 \\
\hline $\mathbf{0 . 9}$ & 12 & 48.00 & 50.00 & 50.00 & 52.00 & 50.00 & 2.95 & 5.00 \\
\hline $\mathbf{1 . 0}$ & 8 & 32.00 & 33.33 & 66.67 & 68.00 & 66.70 & 3.00 & 5.43 \\
\hline
\end{tabular}

Table.4 Effect of chemical mutagen on vegetative parameters of Hibiscus rosa-sinensis L. cv. Red Single

\begin{tabular}{|c|c|c|c|c|c|c|c|c|c|}
\hline \multirow{2}{*}{$\begin{array}{l}\text { Concentration } \\
(\%)\end{array}$} & \multicolumn{3}{|c|}{ Shoot length $(\mathrm{cm})$} & \multicolumn{3}{|c|}{ Leaf length $(\mathrm{cm})$} & \multicolumn{3}{|c|}{ Leaf width $(\mathrm{cm})$} \\
\hline & Actual & $\begin{array}{l}\text { \%over } \\
\text { control }\end{array}$ & $\begin{array}{l}\% \\
\text { reduction } \\
\text { over } \\
\text { control }\end{array}$ & Actual & $\begin{array}{l}\text { \%over } \\
\text { control }\end{array}$ & $\begin{array}{l}\% \\
\text { reduction } \\
\text { over } \\
\text { control }\end{array}$ & Actual & $\begin{array}{l}\% \\
\text { over } \\
\text { control }\end{array}$ & $\begin{array}{l}\% \\
\text { reduction } \\
\text { over } \\
\text { control }\end{array}$ \\
\hline $\mathbf{0}$ & 29.70 & 100.00 & ---- & 4.85 & 100 & --- & 3.20 & 100 & --- \\
\hline 0.1 & 26.52 & 89.29 & 10.71 & 4.72 & 97.32 & 2.68 & 3.10 & 96.88 & 3.13 \\
\hline 0.2 & 25.35 & 85.35 & 14.65 & 4.68 & 96.49 & 3.51 & 2.95 & 92.19 & 7.81 \\
\hline 0.3 & 25.11 & 84.55 & 15.45 & 4.60 & 94.85 & 5.15 & 2.92 & 91.25 & 8.75 \\
\hline 0.4 & 22.50 & 75.76 & 24.24 & 4.50 & 92.78 & 7.22 & 2.83 & 88.44 & 11.56 \\
\hline 0.5 & 20.72 & 69.76 & 30.24 & 4.10 & 84.54 & 15.46 & 2.68 & 83.75 & 16.25 \\
\hline 0.6 & 18.69 & 62.93 & 37.07 & 3.75 & 77.32 & 22.68 & 2.54 & 79.38 & 20.63 \\
\hline 0.7 & 17.50 & 58.92 & 41.08 & 3.52 & 72.58 & 27.42 & 2.25 & 70.31 & 29.69 \\
\hline 0.8 & 15.24 & 51.31 & 48.69 & 2.95 & 60.82 & 39.18 & 2.15 & 67.19 & 32.81 \\
\hline 0.9 & 13.75 & 46.30 & 53.70 & 2.80 & 57.73 & 42.27 & 1.95 & 60.94 & 39.06 \\
\hline 1 & 10.58 & 35.62 & 64.38 & 2.35 & 48.45 & 51.55 & 1.50 & 46.88 & 53.13 \\
\hline Mean & 20.51 & & & 3.89 & & & 2.55 & & \\
\hline S.Ed & 2.34 & & & 0.44 & & & 0.29 & & \\
\hline $\mathrm{CD}(5 \%)$ & 4.89 & & & 0.92 & & & 0.60 & & \\
\hline
\end{tabular}


Fig.1 Plot of log-doses versus Probits for calculation of LD 50 for gamma rays

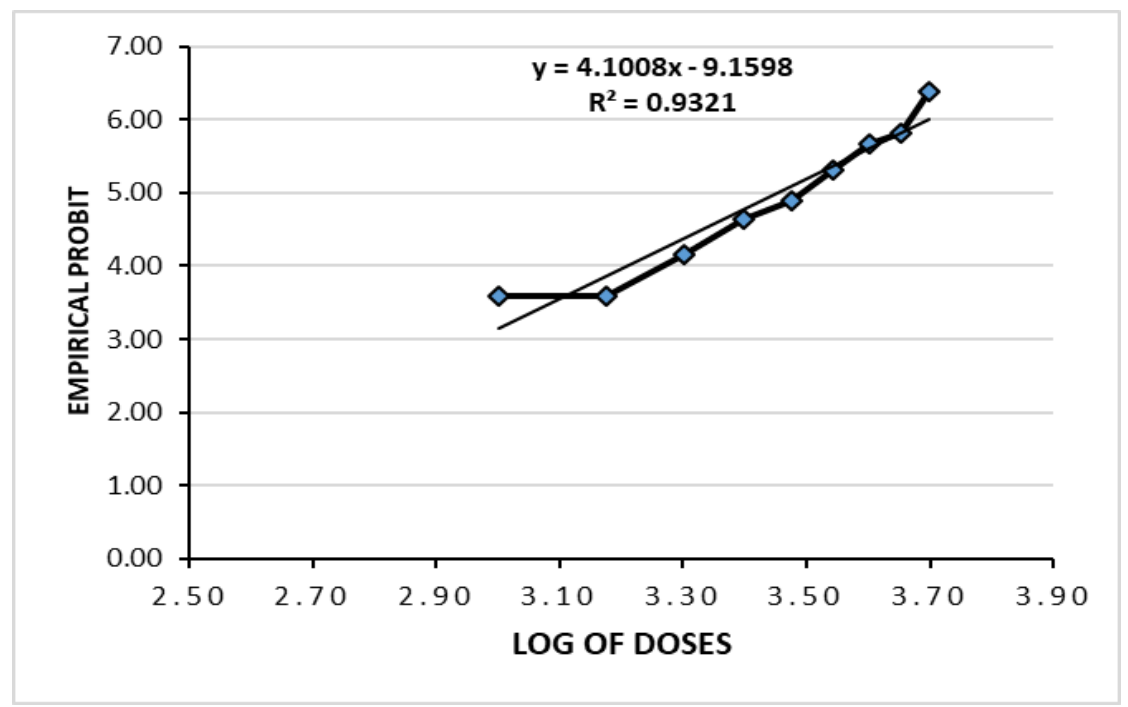

Fig.2 Plot of log-doses versus Probits for calculation of LD 50 for EMS

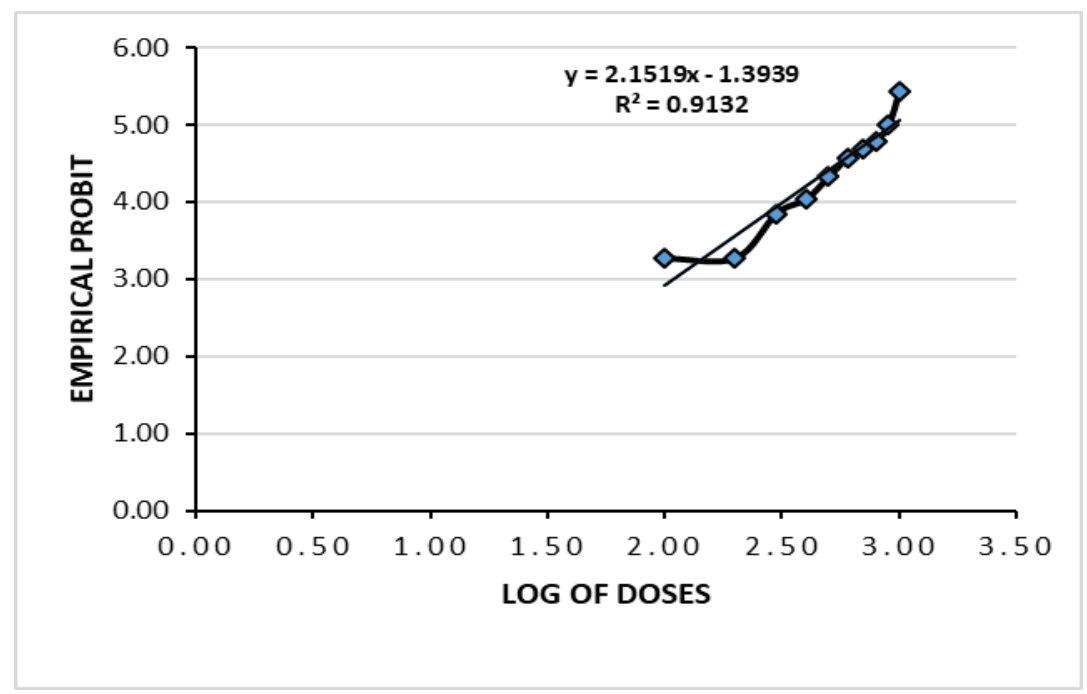

In case of EMS, only survival percentage was taken into consideration for fixing $\mathrm{LD}_{50}$ values, since EMS alkylates guanine bases leads to mispairing of alkylated $\mathrm{G}$ which pairs with $\mathrm{T}$ instead of $\mathrm{C}$, resulting in primarily $\mathrm{G} /$ C- to A/T transitions (Talebi et al., 2012). Based on probit curve (Fig. 2), $\mathrm{LD}_{50}$ for EMS was fixed as $0.89 \%$ (Table 3 ).

In this study, growth related traits were also recorded. Based on the observation on shoot length, leaf length and leaf width, there was a declining trend with increase in applied mutagens when compared with control. The lower values for shoot length, leaf length and width were noticed with the application of higher doses of both the mutagens namely 5 $\mathrm{kR}$ gamma ray and $1.0 \%$ EMS (Table $2 \& 4$ ). When considering the shoot length in both gamma irradiation and EMS treatment, there was a gradual reduction towards the increase in mutagen application when compared to control. The influence of gamma rays on the meristematic regions eventually affects the 
cell division or cell enlargement is well known in many species. The results showed that the differences among mutation treatments considerably influenced the survival shoot length, leaf length and width of the leaves. Moreover, with increase in the intensity of EMS concentration, the shoot length, leaf length and width length proportionately decreased in a linear trend. Similar results of decline in the survival percentage as well as shoot length with increase in the gamma irradiation dose and EMS concentration were observed in Bougainvillea Cv. Roseville's Delight (Banerji et al., 1987), cv. Mahara (Datta and Banerji, 1993). Gamma rays induced mutation in chrysanthemum also reported decrease in leaf length with increase in dose of mutagen (Dilta et al., 2003). Same trend of linear reduction in leaf length with increase in dosage of mutagens was reported by Kainthura and Srivastava (2015) in Tuberose (Polianthes tuberosa). Sparrow (1961) while working on cytological effect of radiation, concluded that the decrease in vegetative growth is a result of radiation-induced cytological changes such as chromosomal damages, inhibited mitotic division, degeneration of nuclei, cell enlargement, etc.

Pre-determination of $\mathrm{LD}_{50}$ is an essential part of a mutation research. Further it reduces the wastage of propagative materials and gives a preview on growth of plants in nursery stage. Inducing treatments using physical mutagens found to be more lethal than chemical mutagen at higher doses. It is recommended that growth rate can also be considered for fixing $\mathrm{LD}_{50}$ in physical mutation. Mutants usually found at higher doses where lethality is high, in case of vegetatively propagated plant like Hibiscus, it is better to isolate the mutants obtained from higher doses. Though plants number will be minimum, it can be increased by multiplying the existing mutant plants by propagating through cuttings.
From this study, it is concluded that, $\mathrm{LD}_{50}$ dose for gamma radiation and EMS have been fixed as $2.81 \mathrm{kR}$ and $0.89 \%$ respectively. This range can be regarded as suitable for inducing effective mutation in Hibiscus rosa-sinensis L. Cultivar Red Single. Based on this, $\mathrm{M}_{1} \mathrm{~V}_{1}$ generation can be established in hibiscus, growth and flowering characters shall be observed throughly inorder to isolate a novel mutant.

\section{References}

Anitha, K., Surendranath, R., Jawaharlal, M., and Ganga, M. 2017. Mutagenic effectiveness and efficiency of gamma rays and ethyl methane sulphonate on Bougainvillea spectabilis willd. (cv. Lalbagh). International Journal of BioResource \& Stress Management, 8(2)

Anonymous: Manual on mutation breeding (2nd edn). 1977. Technical Reports Series No. 119. International Atomic Energy Agency, Vienna.

Banerji, B.K., Nath, P. and Datta, S.K. 1987. Mutation breeding in double bracted Bougainvillea cv. 'Roseville Delight'. J. Nuclear Agrl \& Bio., 16: 45-47

Bhat, R., Upadhaya, N., Chaudhury, A., Raghavan, A., Qiu, C., Wang, F., Wu, H., Mcnally, J., Leiung, K. and Till, B. 2007. Chemical and irradiation induced mutants and tilling. Rice functional genomics, 148-180

Datta, S.K. and Banerji, B.K. 1993. Gamma ray induced somatic mutation in chrysanthemum cv. 'Kalyani Mauve'. J. Nuclear Agric. Biol., 22: 19-27

Datta, S.K. and J.A.T. Da Silva. 2006. Role of induced mutagenesis for development of new flower colour and type in ornamentals. Floriculture, ornamentals and plant biotechnology: Advances and topical issues. Global Science Books Ltd., Middlesex, U.K., 1: 640-645.

Deshpande, K.N., Mehetre, S.S. and Pingle, 
S.D. 2010. Effect of different mutagens for induction of mutations in mulberry. Asian J. Exp. Biol. Sci. Spl., Pp. 104108.

Dilta, B.S., Sharma, Y.D., Gupta, Y.C., Bhalla, R. and Sharma, B.P. 2003. Effect of gamma rays on vegetative and flowering parameters of chrysanthemum. J. Ornam. Hort., 6: 328-334.

Finney, D.J., 1978. Statistical Method in Biological Assay. Charles Griffin Co.

Kapadiya, D.B., Chawla, S.L., Patel, A.I. and Ahlawat, T.R. 2014. Exploitation of variability through mutagenesis in Chrysanthemum (Chrysanthemum morifolium Ramat.) var. Maghi. The Bioscan, 9:1799-1804.

Kim, Y., Schumaker, K.S. and Zhu, J.K. 2006. EMS mutagenesis of Arabidopsis. Meth. Mol. Biol., 323: 101-103.

Kumar, S., Prasad, K.V. and Choudhary, M.L. 2006. Detection of genetic variability among Chrysanthemum radiomutants using RAPD markers. Current Sci., 90: 1108-1113.

Mahure, H.R., Choudhary, M.L., Prasad, K.V. and Singh, S.K. 2010. Mutation in chrysanthemum through gamma irradiation. Indian Journal of Horticulture. 67: 356-358.

Menda, N., Semel, Y., Peled, D., Eshed, Y. and Zamir, D. 2004. In silico screening of a saturated mutation library of tomato. Plant J., 38: 861-872.

Okagaki, R.J., Neffer, M.G., Wessler, S.R. 1991. A deletion common to two independently derived waxy mutations of maize. Genetics 127: 425-431.

Rego, L.V. and R.T. Faria. 2001. Tissue culture in ornamental plant breeding review. Crop Breed. Appl. Biot., 1: 285300.

Sparrow, A.H. 1961. Types of ionizing radiations and their cytogenetic effects. Mutation Plant Breeding NAS-NRC, 891, 55-119.

Talebi, Ali Benjavad, Talebi, Amin Benjavad and Shahrokhifar, Behzad. 2012. Ethyl Methane Sulphonate (EMS) Induced Mutagenesis in Malaysian Rice (cv. MR219) for Lethal Dose Determination. American Journal of Plant Sciences, 3, 1661-1665

Yamaguchi, H., Shimizu, A., Hase, Y., Atsushi Tanaka, A., Shikazono, N., Degi, T. and Morishita, T. 2010. Effects of ion beam irradiation on mutation induction and nuclear DNA content in chrysanthemum. Breed. Sci., 60: 398404

\section{How to cite this article:}

Naveena, N., S. Subramanian, M. Jawaharlal, K. Iyanar and Chandrasekhar, C. N. 2020. Determination of Mutagenic Sensitivity in Hibiscus rosa-sinensis L. (Cultivar Red Single) to Physical and Chemical Mutagens. Int.J.Curr.Microbiol.App.Sci. 9(10): 1756-1763. doi: https://doi.org/10.20546/ijcmas.2020.910.213 